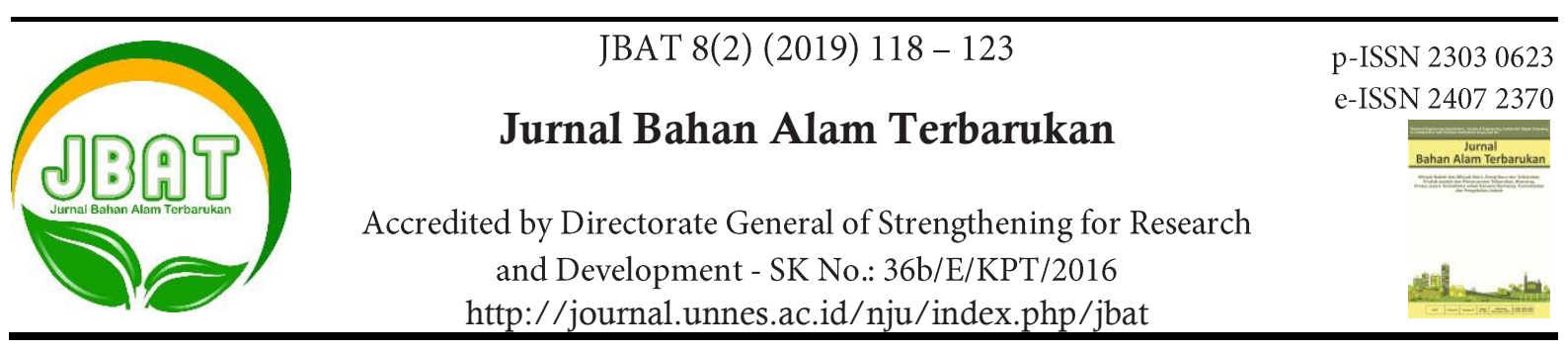

\title{
Kinetics of Sulfide Removal in Biofilter Employing Sulfur-Oxidizing Bacteria on Salak Fruit Seeds
}

\author{
Retno A.S. Lestari ${ }^{1,3, 凶}$, Wahyudi B. Sediawan ${ }^{2}$, Sarto $^{2}$ \\ DOI: https://doi.org/10.15294/jbat.v8i2.22356 \\ ${ }^{1}$ Chemical Engineering Department, University of 17 Agustus 1945 Semarang University, Semarang, \\ Indonesia \\ ${ }^{2}$ Chemical Engineering Department, Gadjah Mada University, Yogyakarta, Indonesia \\ ${ }^{3}$ Center for Environmental and Energy Alternative Studies, 17 Agustus 1945 Semarang University, \\ Semarang, Indonesia
}

\begin{tabular}{|c|c|}
\hline Article Info & Abstract \\
\hline $\begin{array}{l}\text { Article history: } \\
\text { Received } \\
\text { June } 2019 \\
\text { Accepted } \\
\quad \text { November } 2019 \\
\text { Published } \\
\text { December } 2019\end{array}$ & $\begin{array}{l}\text { Sulfur-oxidizing bacterias were isolated then grown on salak fruit seeds forming bio-film. } \\
\text { Their performances in sulfide removal were experimentally observed. The salak fruit seeds } \\
\text { were then used as packing material in a cylinder. Liquid containing } 83 \mathrm{ppm} \text { of sodium } \\
\text { sulfide was flown through the bed. Then the sulfide concentrations in the outlet at various } \\
\text { times were analyzed. A set of simple kinetics model for the rate of the sulfide removal and } \\
\text { the bacterial growth was proposed. The axial sulfide concentration gradient in the flowing }\end{array}$ \\
\hline $\begin{array}{l}\text { Keywords : } \\
\text { Bio-film; } \\
\text { Kinetics model; } \\
\text { Salak fruit seeds; } \\
\text { Sulfide removal; } \\
\text { Sulfur-oxidizing } \\
\text { bacterias }^{-}\end{array}$ & $\begin{array}{l}\text { liquid are assumed to be quasi-steady-state. Mean while the bio-film grows on the surface of } \\
\text { the seeds and the sulfide oxidation takes place in the bio-film. Since the bio-film is very } \\
\text { thin, the sulfide concentration in the bio-film is assumed to be uniform. The simultaneous } \\
\text { ordinary differential equations obtained were then solved numerically using Runge-Kutta } \\
\text { method. The accuracy of the model proposed was tested by comparing the calculation } \\
\text { results using the model with the experimental data obtained. It turned out that the model } \\
\text { proposed can be applied to quantitatively describe the removal of sulfide in liquid using bio- } \\
\text { filter in packed bed. The values of the parameters were also obtained by curve-fitting. }\end{array}$ \\
\hline
\end{tabular}

\section{INTRODUCTION}

Sulfide compounds are causing problems in industries and society such as corrosion of sewer structures, odor nuisance and health impacts on sewer workers operating wastewater collection systems (US Environmental Protection Agency, 1974). Under anaerobic wastewater conditions, sulfides combine with hydrogen to produce hydrogen sulfide. The corrosion of sewer structures is caused by the oxidation of the hydrogen sulfide to sulfuric acid, then the sulfuric acid reacts readily with the alkaline components of the concrete structures such as sewer pipes and manholes (Nielsen et al., 2008).
There are several processes available to remove sulfide, including physical, chemical, and biological processes. The physical and chemical processes such as absorption, combustion, and scrubbing have been used to remove sulfide from industrial waste water streams. But those physical and chemical methods need high energy requirements, high chemical disposal, and high costs (Namini et al., 2007). The commonly applied biological process for sulfide removal is biofiltration (Rattanapan et al., 2009). In this study, bio-filtration was investigated for this application. This method uses microorganisms living in a support matrix to degrade the pollutan. It is expected that this method is inexpensive. This method is very attractive for low concentration gas

${ }^{\square}$ Corresponding author:

Chemical Engineering Department, University of 17 Agustus 1945 (UNTAG)

Semarang, Indonesia

E-mail: retnotengaran@gmail.com 
streams due to the relatively moderate operating cost and minimum by-product generation (Delhomenie \& Heitz, 2005).

Packing material is important to the design of a bio-filtration unit. The packing material must have high porosity and water retention capacity. The presence and availability of nutrients are also important (Delhomenie \& Heitz, 2005). Organic materials have both the presence of nutrients and higher water holding capacity than inorganic packing materials. Most bio-filter media applied are peat and compost with inert bulking agents such as activated carbon, wood chips or beads (Fischer, 2010). Composts are used frequently as they over dense and have more varied microbial population as well as good water holding capacity and nutrients. However, composts have low porosity, so the pressure drop in the bio-filter will be high. Soils are prone to short circuiting and clogging (Delhomenie \& Heitz, 2005). Activated carbon is good, but very expensive (Chung et al., 1996).

In this study, the removal of sulfide in liquid by bio-filter on packed bed was investigated. The experiment employing organic packing material of salak fruit seeds (SFS). Salak fruit seeds were harvested from Sleman, Yogyakarta, Indonesia. These materials offer advantages including low cost, porous, and high water retention capacity. The isolate organism immobilized on salak fruit seeds (SFS) was obtained from microbial culture taken from sludge of the municipal waste water treatment plant in Srandakan, Bantul, Yogyakarta, Indonesia. To generalyze the results, a mathematical model considering liquid to bio-film mass transfer and bio-oxidation in the bio-film is developed.

The objective of this paper is to develop a kinetics model to quantitatively describe the removal of sulfide from a liquid stream using biofilter in packed bed. The model developed was then solved by the finite difference approximation method. The accuracy of the model was then tested by experimental data. Since most of biofilter study did not focus on quantitative description via kinetics models, the quantitative description developed is expected to be useful, such as for better understanding of the phenomena occur as well as for designing larger scale equipment of sulfide removal using bio-filter.

\section{THEORITICAL DEVELOPMENT}

The schematic diagram of the biofilter system is presented in Figure 1. In Figure 1, liquid stream containing sulfide flows past the bio-film. The bio-film contains microorganism and is considered to be fixed to the packing materials. Sulfide is transferred from the liquid to the biofilm, and bacterial action in the biofilm degrades the sulfide. The fundamental processes involved are the transfer of sulfide from liquid stream to the surface of the bio-film, sulfide absorption in the bio-film, and bacterial action in the bio-film to degrade the sulfide compounds.

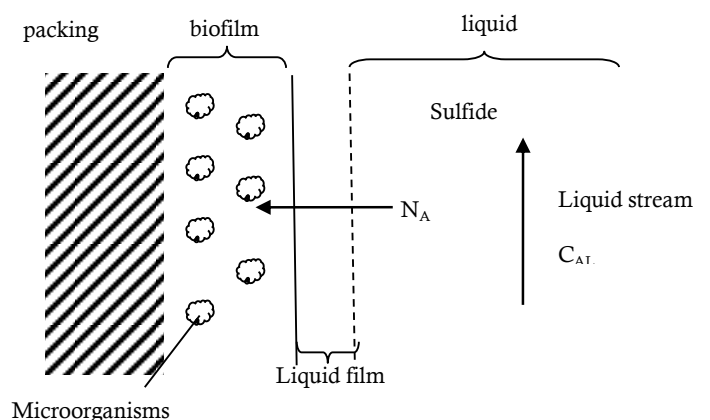

Figure 1. Schematic diagram of biofilter system.

The kinetics model proposed is esentially similar to the model proposed by Lestari et al. (2013). Sulfide concentration in the bio-filter for a given height is considered to be uniform because bio-film thickness $(\delta)$ is relatively small. The microorganism concentration in the bio-film at certain axial position in the bed is also assumed to be uniform. The concentration profile in the biofilm system is presented in Figure 2.

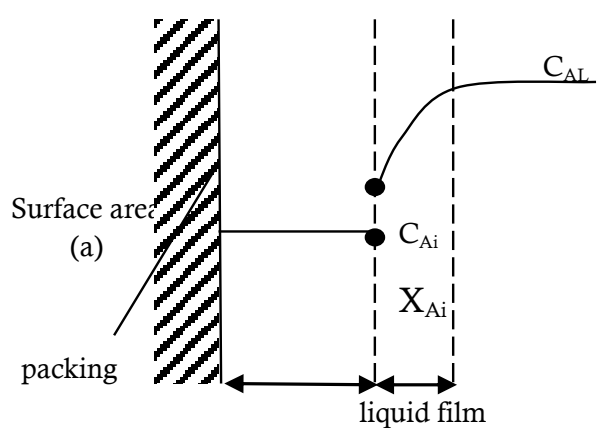

Figure 2. Profile of concentration sulfide in the model.

The mass balance of sulfide in the bio-film is shown in Eqs. (1) - (3). 


$$
\begin{gathered}
{\left[\begin{array}{c}
\text { Rate of } \\
\text { Input }
\end{array}\right]-\left[\begin{array}{c}
\text { Rate of } \\
\text { output }
\end{array}\right]-\left[\begin{array}{l}
\text { Rate of } \\
\text { Reaction }
\end{array}\right]=\left[\begin{array}{c}
\text { Rate of } \\
\text { Accumulation }
\end{array}\right]} \\
k_{C} a\left(C_{A L}-C_{A i}\right)-0-a . \delta . r_{A}=\frac{d X_{A}}{d t} \\
\frac{d X_{A}}{d t}=\frac{k_{C}}{\delta}\left(C_{A L}-C_{A i}\right)-r_{A}
\end{gathered}
$$

Since $\mathrm{C}_{\mathrm{Ai}}$ is in equilibrium with $\mathrm{X}_{\mathrm{Ai}}$, and the equilibrium is assumed to follow coefficient of distribution, so $\mathrm{C}_{\mathrm{Ai}}$ can be written using Eq. (4).

$$
C_{A i}=K_{A} * X_{A i}
$$

The biodegradation rate of sulfide $\left(\mathrm{r}_{\mathrm{A}}\right)$ is approximated by Monod equation as shown in Eq. (6).

$$
r_{A}=\frac{\mu_{\max } X_{A}}{X_{A}+\alpha}
$$

Since the bio-film thickness is $\delta$, the rate of increase of the mass of microorganisms is shown in Eq. (7).

$$
\frac{d m}{d t}=Y . r_{A} \cdot a \cdot \delta
$$

where $\mathrm{Y}$ is contaminant yield coefficient (the ratio of mass of microorganism growth to mass of sulfide consumed). Since the mass of microorganism $\mathrm{m}=\rho \mathrm{a}$, where $\rho$ is mass of microorganism per volume of bio-film, Eq. (6) becomes Eqs. (7) \& (8).

$$
\begin{gathered}
\rho \cdot a \frac{d \delta}{d t}=Y \cdot r_{A} \cdot a \cdot \delta \\
\frac{d \delta}{d t}=\frac{Y}{\rho} \cdot r_{A} \cdot \delta
\end{gathered}
$$

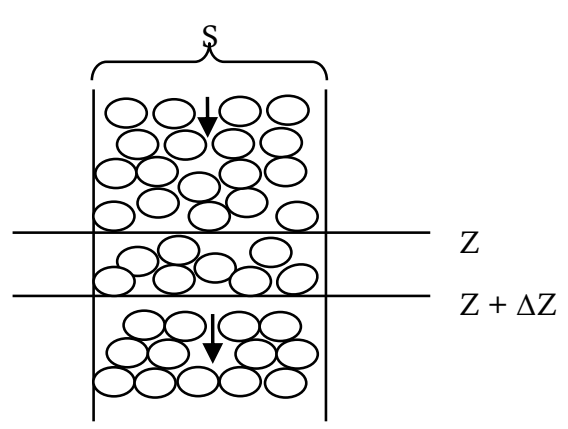

Figure 3. Element Volume in Biofilter.

Mass balance of sulfide in liquid stream in the bed of thickness of $\Delta z$ can be seen in Figure 3.
The governing equation for this case is written in Eqs. (9) - (11).

$$
\begin{aligned}
& \left.F_{V} \cdot C_{A L}\right|_{Z}-\left(\left.F_{V} \cdot C_{A L}\right|_{Z+\Delta Z}-k_{C} \cdot\left(C_{A L}-C_{A i}\right) \cdot a_{S} \cdot S \cdot . \Delta Z\right)=S . \Delta Z \cdot \varepsilon \frac{\partial C_{A L}}{\partial t} \\
& \frac{\left.F_{V} \cdot C_{A L}\right|_{Z+\Delta Z}-\left.F_{V} \cdot C_{A L}\right|_{Z}}{\Delta z}+k_{C}\left(C_{A L}-C_{A i}\right) a_{S} S=-S \varepsilon \frac{\partial C_{A L}}{\partial t}
\end{aligned}
$$

If limit $\Delta z \rightarrow 0$, then

$$
F_{V} \frac{\partial C_{A L}}{\partial z}+k_{C}\left(C_{A L}-C_{A i}\right) a_{s} S=-S \varepsilon \frac{\partial C_{A L}}{\partial t}
$$

For pseudo steady-state process in the liquid phase, $\frac{\partial C_{A L}}{\partial t}=0$, so Eq. (11) can be rewritten as shown in Eq. (12) \& (13).

$$
\begin{gathered}
\frac{F_{V}}{\varepsilon S} \frac{d C_{A L}}{d z}+\frac{k_{C} a_{S}}{\varepsilon}\left(C_{A L}-C_{A i}\right)=0 \\
\frac{d C_{A L}}{d z}=-\frac{k_{C} a_{S} S}{F_{V}}\left(C_{A L}-C_{A i}\right)
\end{gathered}
$$

In conclusion, the mathematical model representing the process is the set of equation of 3 , $4,5,8,11$ and 13 . To verify the accuracy of the mathematical model, the experimental data are applied.

\section{MATERIALS AND METHODS}

\section{Materials}

The material peparation was conducted according to Lestari et al. (2014). Salak fruit seeds were harvested from Sleman, Yogyakarta, Indonesia. The salak fruit seeds were washed and then dried in an oven at $55^{\circ} \mathrm{C}$ to eliminate all volatile impurities and the water. Sludge was taken from the municipal waste water treatment plant in Srandakan, Bantul, Yogyakarta, Indonesia. Sludge sample was used as inoculum seed. For the growth of mixed culture, the SOB medium of $0.4 \mathrm{~g} / 1$ $\mathrm{NH}_{4} \mathrm{Cl}, 0.2 \mathrm{~g} / 1 \mathrm{MgCl} .6 \mathrm{H}_{2} \mathrm{O}, 0.2 \mathrm{~g} / 1 \mathrm{KH}_{2} \mathrm{PO}_{4}, 0.2$ $\mathrm{g} / 1 \mathrm{~K}_{2} \mathrm{HPO}_{4}, 0.2 \mathrm{~g} / 1$ yeast extract and $8 \mathrm{~g} / 1$ $\mathrm{Na}_{2} \mathrm{~S}_{2} \mathrm{O}_{3} \quad .5 \mathrm{H}_{2} \mathrm{O}$ was used (Lestari et al., 2014). Medium and equipment were autoclaved and sterilized at $121^{\circ} \mathrm{C}, 1.2$ atm for $15 \mathrm{~min}$.

\section{Cultivation of Microorganism}

The cultivation of microorganism was conducted according to Lestari et al. (2014). The 


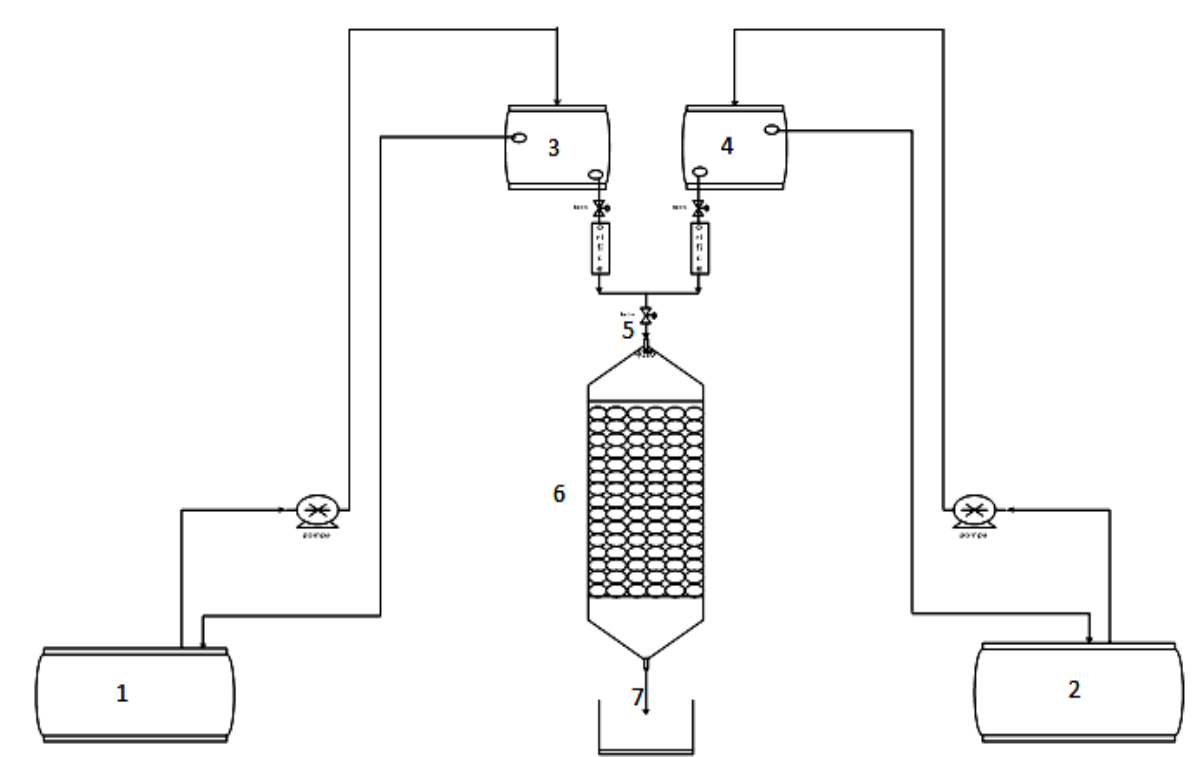

Figure 4. Experimental set-up: (1) sulfide tank; (2) nutrient tank; (3) sulfide feeder tank; (4) nutrient feeder pump; (5) valve; (6) bio-filter, and (7) outlet port.

mixed microbial culture used for the removal of sulfide was made by suspending about $25 \mathrm{~g}$ of sludge in $50 \mathrm{ml}$ of sterile distilled water, then the mixture was shaken vigorously. The resulting cell suspension was enriched with SOB medium. The enrichment cultures were started by seeding $5 \mathrm{ml}$ of cell suspension into $250 \mathrm{ml}$ of SOB medium. At the same time, $25 \mathrm{~g}$ of salak fruit seeds (SFS) was added into $250 \mathrm{ml}$ of inoculum. The cultivation was conducted under aerobic condition. All enriched culture flasks were incubated at $30^{\circ} \mathrm{C}$ on a rotary shaker at $180 \mathrm{rpm}$ for 9 days. The cell number of microbial immobilization on SFS was estimated every day by the traditional platecounting method using SOB medium.

\section{Isolation of Sulfur-Oxidizing Bacterium}

The isolation of sulfur-oxidizing bacterium was conducted according to Lestari et al. (2014). After 4 days, the microorganisms immobilized on SFS reached $1.26 \times 10^{7} \mathrm{cfu} / \mathrm{g}$ dry SFS. Fiveteen colonies, which had different shapes and colour, were isolated and then to be tested to find which one having the highest sulfur oxidation capability. The selected isolates were then cultivated in fresh SOB + Yeast Extract (YE) liquid medium with the same manner as described above. Growth and sulfur oxidation activity of the isolate was examined in the SOB + YE medium. The control test was performed by conducting sulfur removal using supplement medium containing sodium thiosulfate without the isolate. To test the performance of bacteria on salak fruit seeds, the effect of each isolate on SFS were observed. Each isolated organism was grown in a $500 \mathrm{ml}$ erlenmeyer flask at atmospheric pressure. The erlenmeyer containing $250 \mathrm{ml}$ of liquid media was inoculated with $25 \mathrm{ml}$ of culture. At the same time, $200 \mathrm{~g}$ of SFS was added into $250 \mathrm{ml}$ of inokulum. The cultivation was conducted under aerobic condition. All enriched culture flasks were incubated at $30{ }^{\circ} \mathrm{C}$ for 6 days. After about 6 days of immobilization, the salak fruit seeds were transferred to the erlenmeyer flask and $\mathrm{Na}_{2} \mathrm{~S}$ solution was added to test the performance of the microbes on the salak fruit seeds. From the experiment, it was observed that isolate 12 was the best for degradation of sulfide.

\section{Biofilter Experiments}

Preliminary batch experiments suggested that isolate 12 was the promising bio-film for sulfide removal. This isolate performance was further tested in a packed bed column experiments. The isolate organism was immobilized on SFS for about one week. About $2.5 \mathrm{~kg}$ of dried SFS and $3000 \mathrm{ml}$ of SOB medium was mixed in a flask and was autoclaved. The mixture was then sterilized at $121^{\circ} \mathrm{C}$ and $1.2 \mathrm{~atm}$ for $15 \mathrm{~min}$. About $10 \%$ of microorganism seed was then grown at $30{ }^{\circ} \mathrm{C}$ and at atmospheric pressure. After one week, the biofilm was grown on SFS surface, and then was subsequently submitted in the bio-filters. Prior to the continuous experiments, the SOB medium was added to the bio-filter to feed the microorganism. 
The experimental equipment used in this work was showed in Figure 4 . The bio-filter was constructed of a acrilics column with $8 \mathrm{~cm}$ of inside diameter and $100 \mathrm{~cm}$ of height, packed with SFS as high as $70 \mathrm{~cm}$. About $83 \mathrm{ppm}$ or 0.083 $\mathrm{g} / \mathrm{cm}^{3}$ of $\mathrm{Na}_{2} \mathrm{~S}$ solution entered the packing from a port in the top of the column where it passed through the bio-filter at the rate of $2.0833 \mathrm{~cm}^{3} / \mathrm{s}$ or 7.5 L/hr. The liquid samples were taken from the outlet at every 3 hours and the sulfide concentration were analyzed using spectrophotometer at $664 \mathrm{~nm}$ wavelength.

\section{RESULTS AND DISCUSSION}

The sulfide concentration in the feed was $83 \mathrm{ppm}$. The experimental result of the sulfide removal in bio-filter by isolate 12 on SFS was showed in Figure. 5. It can be seen that isolate 12 on SFS can decrease the sulfide content from 83 ppm to 0.869 ppm for 54 hours. At that time the thickness of bio-film was assumed to be very small. The comparison between the simulation results and the experimental data can be seen in Figure 5 . It can be observed from Figure 5 that the simulation results are close to the experimental data. So it can be concluded that the mathematical model proposed can be applied to describe the removal of sulfide liquid using bio-filter in packed bed. In Figure 5, the calculation was done using the parameter values as follows: $\mu_{\max }=0.0005$ (1/day), $\alpha=0.0025\left(\mathrm{~g} / \mathrm{cm}^{3}\right), \mathrm{k}_{\mathrm{C}}=0.0022(\mathrm{~cm} / \mathrm{sec})$, $\mathrm{K}_{\mathrm{A}}=0.3\left(\left(\mathrm{~g} / \mathrm{cm}^{3}\right) /\left(\mathrm{g} / \mathrm{cm}^{3}\right)\right)$, and $\mathrm{Y}=100$. Those values were obtained by curve-fitting. From the simulation, it can be concluded that $\mathrm{k}_{\mathrm{C}}$ strongly effects the concentration of sulfide at the outlet liquid after the process is relatively stable. On the other hand, $\mu_{\max }$ and $Y$ strongly affect the rate to achieve the stable process.

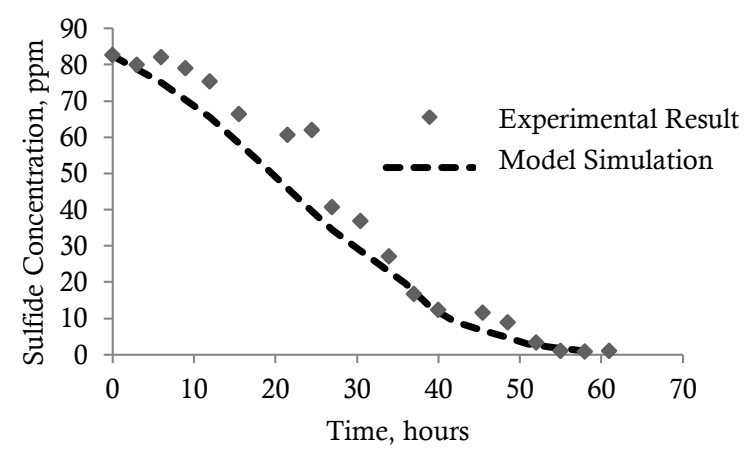

Figure 5. Sulfide Concentration vs Times for experiment result and model simulation.
Based on the volum of the liquid in the column and the flow rate of the liquid the residental time of the liquid in the column is approximately 50 minutes. The experiment shows that the sulfide removal in column is $98 \%$. These data show that the rate of the sulfur removal by the bio-film in the column is relatively high. Other advantage of using column is that the process can operate continously, eventhought the start-up time to develop the bio-film is relatively long (55 hours). As a comparison, the time needed to achieve $98 \%$ removal of sulfide in batch bioreactor at 35 hours. This means that the star-up time of the biofilter column is longer than the batch removal time. But after that, the column can operate relatively fast continously.

Chung et al. (1996) reported that $98 \%$ removal of sulfur from gas phase in packed bed bio-reactor was achieved at retention time of $28 \mathrm{~s}$. This is very fast compared to our result in liquid phase (50 minutes). This comparison shows that the sulfur removal from liquid phase is much slower than the one from gas phase. It is conceivable since generally that processes in gas phase run much faster than the ones in liquid phase.

\section{CONCLUSION}

From this study the following can be concluded that the isolate 12 on salak fruit seeds can eliminate sulfide from $83 \mathrm{ppm}$ to $0.869 \mathrm{ppm}$ after 61 hours. The mathematical model proposed can be applied to quantitatively describe the removal of sulfide using bio-filter in packed bed of salak fruit seeds. The values of the parameters obtained are $\mu_{\max }=0.0005(1 / \mathrm{s}), \alpha=$ $0.0025\left(\mathrm{~g} / \mathrm{cm}^{3}\right), \mathrm{k}_{\mathrm{C}}=0.0045(\mathrm{~cm} / \mathrm{sec}), \mathrm{K}_{\mathrm{A}}=0.3$ $\left(\left(\mathrm{g} / \mathrm{cm}^{3}\right) /\left(\mathrm{g} / \mathrm{cm}^{3}\right)\right)$, and $\mathrm{Y}=100$. The value of $\mathrm{k}_{\mathrm{C}}$ strongly effects the concentration of sulfide at the outlet liquid after the process is relatively stable. The values of $\mu_{\max }$ and $Y$ strongly affect the rate to achieve the stable process.

\section{NOMENCLATURE}

$a_{s} \quad$ Ratio of surface area of bio-film to bed volume $\left(\mathrm{cm}^{2} / \mathrm{cm}^{3}\right)$

$\mathrm{C}_{\mathrm{AL}} \quad$ Sulfide concentration in liquid $\left(\mathrm{g} / \mathrm{cm}^{3}\right)$

$\mathrm{C}_{\mathrm{Ai}} \quad$ Sulfide concentration in liquid interface $\left(\mathrm{g} / \mathrm{cm}^{3}\right)$

$\mathrm{F}_{\mathrm{V}} \quad$ Debit of liquid stream $\left(\mathrm{cm}^{3} / \mathrm{s}\right)$ 
$\mathrm{K}_{\mathrm{A}} \quad$ Constant in equation (4)

$\mathrm{k}_{\mathrm{C}} \quad$ Mass transfer coefficient from liquid to biofilm $(\mathrm{cm} / \mathrm{s})$

$\mathrm{r}_{\mathrm{A}} \quad$ Rate of degradation $\left(\mathrm{g} / \mathrm{cm}^{3} / \mathrm{s}\right)$

$\mathrm{S} \quad$ Cross section area of the bed $\left(\mathrm{cm}^{2}\right)$

$\mathrm{t} \quad$ Time (s)

$\mathrm{X}_{\mathrm{Ai}} \quad$ Sulfide concentration in bio-film interface $\left(\mathrm{g} / \mathrm{cm}^{3}\right)$

$\mathrm{X}_{\mathrm{A}} \quad$ Sulfide concentration in bio-film $\left(\mathrm{g} / \mathrm{cm}^{3}\right)$

$\mathrm{Y} \quad$ Ratio of mass of microorganism growth to mass of sulfide consumed

$\mathrm{z} \quad$ Axial position in the bed $(\mathrm{cm})$

Greek Symbol

$\alpha \quad$ Constant in Monod equation $(\mathrm{g} / \mathrm{cm} 3)$.

$\delta \quad$ Thickness of bio-film (cm)

$\varepsilon \quad$ Porosity

$\rho \quad$ Mass of microorganisms to bio-film volume $(\mathrm{g} / \mathrm{m} 3)$

$\mu_{\max } \quad$ Rate of maximum spesific growth $(1 / \mathrm{s})$

Abbreviations

SFS Salak Fruit Seed

SOB Sulfur Organism Bacteria

\section{REFERENCES}

Chung, Y. C., Huang, C., Tseng, C. P., Pan, J. R. 1996. Microbial Oxidation of Hydrogen Sulphide with Bio-filter. Journal of Environmental Science and Health - Part A Toxic/Hazardous Substances and Environmental Engineering. 31(6): 12631278.

Delhomenie, M. C., Heitz, M. 2005. Bio-filtration of Air: A Review. Critical Reviews in Biotechnology. 25(1-2): 53-72.

Fischer, M., E. 2010. Biogas Purification: $\mathrm{H}_{2} \mathrm{~S}$ Removal using Bio-filtration. M. A. Sc. Thesis, Grad. Department of Chemical Engineering, University of Waterloo. Ontario, Canada.

Lestari, R. A. S., Sediawan, W. B., Syamsiah, S., Sarto, S. 2013. Development of
Quantitative Model for Predicting $\mathrm{H}_{2} \mathrm{~S}$ Removal from Biogas using Microbial Film, in : International Proceeding of $20^{\text {th }}$ Regional Symposium on Chemical Engineering (RSCE 2013). Bohol, Phillipines. 131-135.

Lestari, R. A. S., Sediawan, W. B., Syamsiah, S., Sarto, S. 2014. The Exploratory Study on Sulfide Removal Ability of SulfurOxidizing Bacteria in Biofilm on Salak Fruit Seeds, in: International Proceeding of Chemical, Biological \& Environmental Engineering, Chemical Engineering and Applications. Taipei, Taiwan. 16-19.

Namini, M. T., Heydarian, S. M., Bonakdarpour, B., Farjah, A. 2007. Removal of $\mathrm{H}_{2} \mathrm{~S}$ from synthetic waste gas streams using a biotrickling filter. Iranian Chemical Engineering Journal. 5(3): 40-51.

Nielsen, A. H., Vollertsen, J., Jensen, H. S., Madsen, H. I., Hvitved-Jacobsen, T. 2006. Aerobic and Anaerobic Transformation of Sulfide in a Sewer System-Field Study and Model Simulation. Water Environment Foundation. 80(1): $16-25$.

Rattanapan, C., Boonsawang, P. Kantachote, D. 2009. Removal of $\mathrm{H}_{2} \mathrm{~S}$ in Down-flow GAC Bio-filtration using Sulfide Oxidizing Bacteria from Concentrated Latex Wastewater. Bioresources Technology. 100(1): 125-130.

Shahmansouri, M. A., Taghipour, H., Bina, B., Movahdian, H. 2005. Biological Removal of Ammonia from Contaminated Air Stream using Biofiltration System. Iranian Journal of Environmental Health Science and Engineering. 2(2): 17-25.

U.S. Environmental Protection Agency. 1974. Process Design Manual for Sulfide Control in Sanitary Sewerage Systems. EPA-625/1-74-005. Washington, D.C. 